\title{
MICROTEACHING DALAM JARINGAN BERBASIS LESSON STUDY DAN PENINGKATAN KETERAMPILAN MENGAJAR SERTA PENGEMBANGAN LESSON PLAN
}

\author{
${ }^{1)}$ Herry Agus Susanto, ${ }^{2) *}$ Erika Laras Astutiningtyas, ${ }^{3)}$ Dewi Susilowati \\ $\left.{ }^{1,2}\right)$ Universitas Veteran Bangun Nusantara Sukoharjo \\ *) astutiningtyas.univet@gmail.com
}

Received:
06/05/2021
Accepted:
09/06/2021
Published:
23/06/2021

\begin{abstract}
The purpose of this study is to improve skills in developing Lesson Plans and teaching skills for students. This type of research is a descriptive study with a qualitative approach. The research subjects were 11 students of the Mathematics Education Study Program, Teacher Training and Education Faculty, Universitas Veteran Bangun Nusantara Sukoharjo. The research was conducted on Microteaching Courses which were conducted based on Lesson Study. Recovery is carried out in a network using several platforms, namely: YouTube, the Learning System in the Universitas Veteran Bangun Nusantara Sukoharjo Network with the Moodle, Zoom, and WhatsApp application platforms. The method of data collection is carried out by the method of observation. The instruments used in this study were: Teaching skills assessment sheet and lesson plan assessment sheet. The two instruments are carried out to assess teaching skills and the Learning Implementation Plan in Open Lesson I, II, and III. Based on the results of the study, it was found that the change in the average score of 11 students who practiced their skills in developing Lesson Plans starting from $76.636 ; 84,182 ; 88,364$. For teaching skills, the changes are as follows: 76,818; 83,$909 ; 87,182$. So the result of this research is that the implementation of Microteaching in a network based on Lesson Study can improve students' abilities in compiling Lesson Plans and student teaching skills.
\end{abstract}

Keywords: Lesson Study, Microteaching, Online Learning

\begin{abstract}
Abstrak
Tujuan penelitian ini adalah untuk meningkatkan keterampilan mengembangkan Lesson Plan dan keterampilan mengajar bagi mahasiswa. Jenis penelitian yang dilakukan adalah penelitian deskriptif dengan pendekatan kualitatif. Subyek penelitian adalah 11 orang Mahasiswa Program Studi Pendidikan Matematika, Fakultas Keguruan dan Ilmu Pendidikan Universitas Veteran Bangun Nusantara Sukoharjo. Penelitian dilakukan pada Mata Kuliah Microteaching yang dilaksanakan berbasis Lesson Study. Perkulihan dilaksanakan dalam jaringan menggunakan beberapa platform yaitu: YouTube, Sistem Pembelajaran dalam Jaringan Universitas Veteran Bangun Nusantara Sukoharjo dengan platform Moodle, Zoom, dan aplikasi WhatsApp. Metode pengumpulan data dilakukan dengan metode observasi. Instrumen yang digunakan dalam penelitian ini adalah: Lembar penilaian keterampilan mengajar dan lembar penilaian Rencana Pelaksanaan Pembelajaran. Kedua instrumen tersebut dilakukan untuk melakukan penilaian keterampilan mengajar dan Rencana Pelaksanaan Pembelajaran pada Open Lesson I, II, dan III. Berdasar hasil penelitian diperolah bahwa perubahan rata-rata skor 11 mahasiswa praktikan untuk keterampilan mengembangkan Lesson Plan dimulai dari 76,636; 84,182; 88,364. Untuk keterampilan mengajar, perubahannya adalah sebagai berikut: 76,$818 ; 83,909 ; 87,182$. Jadi hasil dari penelitian ini adalah implementasi Microteaching dalam jaringan berbasis Lesson Study dapat meningkatkan kemampuan mahasiswa dalam menyusun Lesson Plan dan keterampilan mengajar mahasiswa.
\end{abstract}

Kata Kunci: Lesson Study, Microteaching, Pembelajaran Daring 


\section{Pendahuluan}

Guru memegang peranan penting dalam proses pembelajaran. Pemerintah telah menjalankan berbagu upaya dalam rangka peningkatan kualitas pendidikan, salah satunya adalah dengan penetapan standar proses pendidikan. Keberhasilan usaha ini akan sangat bergantung pada pelaksananya yaitu guru (Fahdini et al., 2014). Kompetensi guru meliputi aspek pengetahuan, keterampilan, dan perilaku, yang kesemuanya harus dimiliki, dipahami, serta diaplikasikan dalam melaksanakan tugas profesional guru (Andina, 2018). Sesuai dengan Pasal 8 UU Republik Indonesia No. 14. Tahun 2005, kompetensi guru meliputi beberapa kompetensi, yaitu: kompetensi pedagogik, kepribadian, profesional, dan sosial. Kompetensi-kompetensi tersebut dapat diperoleh melalui pendidikan profesi. Tedjawati menyatakan bahwa empat kompetensi guru tersebut harus dilaksanakan secara integratif dan holistik oleh guru dalam melaksanakan tugasnya, sehingga secara utuh, ketika medeskripsikan sosok seorang guru harus mempu: (1) mengenali secara mendalam peserta didiknya; (2) menguasai bidang studinya baik dalam hal diciplinary content maupun dalam hal pedagogical content; (3) mampu menyusun perencanaan pembelajaran, melaksanakan proses pembelajaran sampai pada melaksanakan kegiatan evaluasi proses serta hasil belajar, untuk selanjutnya melakukan kegiatan perbaikan dan pengayaan; (4) melaksanakan kegiatan pengembangan keprofesian berkelanjutan serta pengembangan kepribadian (Tedjawati, 2011).

Pada penelitian ini hanya akan dibahas mengenai kompetensi profesional. Tedjawati juga menyebutkan bahwa kompetensi profesional adalah kemampuan yang harus dimiliki oleh seorang guru dalam menguasai bidang ilmu yang diajarkannya (Tedjawati, 2011). Penguasaan yang dimaksud disini meliputi beberapa hal sebagai berikut: (1) menguasai materi pembelajaran yang diajarkan, secara mendalam dan komprehensif; (2) menguasi konsep-konsep serta metode disiplin keilmuan yang diampu.

Salah satu komponen penting dalam meningkatkan kualitas proses pembelajaran adalah pengembangan perencanaan pembelajaran oleh guru. Anggraeni dan Akba menyatakan bahwa "Lesson plan is one of important role in the teaching and learning process in Primary Schools. It contains plans for activities or activities that will be carried out during learning" (Anggraeni \& Akbar, 2018). Pendapat tersebut sejalan dengan pendapat Arman yang menyatakan bahwa untuk melaksanakan perubahan besar 
dalam dunia pendidikan pendidikan, bukan hanya dilakukan dengan melakukan perubahan kurikulum saja, baik dalam hal struktur dan prosedur penulisannya (Arman, 2016). Perombakan kurikulum yang diikuti dengan pelaksanakannya dalam proses pembelajaran akan menjadi hal yang sangat penting untuk membut perubahan tersebut menjadi bermakna. Keterampilan guru dalam mengaplikasikan dan mengaktualisasikan kurikulum menjadi salah satu hal yang sangat mempengaruhi tingkat keberhasilan dari perubahan dan implementasi kurikulum tersebut. Beberapa hal yang mungkin menyebabkan tidak terlaksananya implementasi kurikulum adalah kurangnya pengetahuan serta keterampilan guru dalam memahami apa yang harus dilaksakana dalam rangka mengaktualisasikan kurikulum. Berdasarkan hal tersebut, dapat dikatakan bahwa guru adalah sosok kunci dalam perombakan kurikulum.

Lesson study merupakan suatu analisis kasus proses pembelajaran yang mulai dikenalkan di negara Jepang pada tahun 1900-an. Tujuan dilaksanakannya kegiatan Lesson Study ini adalah untuk memfasilitasi pengembangan profesionalisme guru. Selain itu, juga ditujukan untuk membuka kesempatan bagi guru-guru untuk dapat saling belajar melalui praktik pembelajaran kelas. Lesson study is a method that can be used in pre-service teacher training, in-service teacher training, and on-service teacher training (Karim, 2006). Menurut Anggara dan Chotimah (2012) lesson Study sejatinya merupakan suatu model pembinaan keprofesian guru. Tujuan dari kegiatan ini adalah untuk meningkatkan kualitas kinerja guru. Kegiatan lesson Study dilaksanakan bersamasama oleh sekelompok guru. Yang harus diperhatikan disini adalah, lesson study bukan suatu metode ataupun strategi pembelajaran, akan tetapi pada kegiatan lesson study seorang guru dapat menentukan dan mengaplikasikan berbagai model, metode atau strategi pembelajaran sesuai dengan situasi peserta didik serta dapat digunakan untuk mengatasi permasalahan yang ada pada kegiatan pembelajaran (Vitantri \& Asriningsih, 2016). Bagaimana menarik perhatian siswa selama pembelajaran, bagimana menindaklanjuti dan merencanakan perubahan dalam pembelajaran akan sangat membantu kemajuan siswa (Sjunnesson, 2020). Seluruh hal tersebut dapat diupayakan dalam lesson study. Hal ini selajan dengan pendapat yang menyatakan bahwa implementasi blended learning dengan model pembelajaran flipped classroom berbasis lesson study for learning community memberikan pengaruh yang signifikan terhadap keterampilan berfikir kreatif siswa (Sya'Roni et al., 2020). Begitu juga dengan pendapat yang menyatakan bahwa lesson study for learning community-based collaborative 
learning-integrated realistic mathematics education improved the students' mathematical reasoning ability (Kusumawati, 2020). Sehingga berdasarkan beberapa hal tersebut diharapkan implementasi lesson study akan memberikan dampak positif terhadap siswa. Lebih luas lagi, lesson study dilaksanakan tidak hanya untuk mengatasi permasalahan-permasalahan yang dihadapi dalam proses pembelajaran, akan tetapi, lesson study dilaksanakan untuk membangun sebuah pola atau jalur untuk memfasilitiasi kegiatan instruksional yang dilaksanakan (Agustiana et al., 2018). Selain untuk peserta didik, manfaat lesson study juga dapat dirasakan oleh pemgajar, sesuai dengan pendapat Alamri (2020) yang menyatakan bahwa implementasi lesson study memberikan pengaruh yang kuat terhadap pengembangan profesionalitas guru matematika, karena melalui lesson study, guru dibantu untuk meningkatkan pengetahuan tentang keilmuan matematika dan pedagogis mereka, meningkatkan pengetahuan mereka tentang proses pembelajaran bagi siswa siswa serta mempengaruhi pandangan mereka tentang lesson study. Hal ini sejalan dengan pendapat yang menyatakan bahwa metode guru dalam mengajar memegang peranan penting dalam meningkatkan kualitas pembelajaran di sekolah (Tachie, 2020). Oleh karena itu membutuhkan sebuah pengembangan kompetensi yang berkesinambungan dari waktu ke waktu bagi guru, salah satunya dengan lesson study.

Rohaeti dan Hendriana (2016) menyebutkan bahwa kegiatan langkah-langkah kegaiatan Lesson study sebagai berikut. Kegiatan diawali dengan sesi Plan. Pada kegaiatan Plan tim pengajar melakukan diskusi untuk menyusun perencanaan dan desain pembelajaran. Perencanaan dan desain pembelajaran yang disusun oleh tim mengajar memperhatikan beberapa hal sebagai berikut: karakteristik materi ajar, karakteristik peserta didik. Selain itu dalam kegiatan ini juga dibahas mengenai media pembelajaran yang akan dimanfaatkan dalam proses pembelajaran. Pada kegiayan Plan juga dilakukan penunjukan seorang pengajar untuk menjadi guru model. Guru model adalah anggota tim pengajar yang akan melaksanakan kegaiatan pembelajaran pada kegiatan Do (Open Lesson). Setelah kegiatan plan dilaksanakan, selanjutnya dalah melaksanakan perencanaan yang telah disusun pada kegiatan pembelajaran sesungguhnya. Kegiatan ini dinamakan dengan Do, yang nantinya pelaksanaan pembelajaran dilakukan oleh seorang guru model yang telah ditetapkan pada kegaiatan Plan. Pengajar lain berperan sebagai pengamat jalannya proses pembelajaran atau biasa disebut dengan Observer. Setelah kegiatan Do dilaksanakan, selanjutnya masuk ke 
tahap kegiatan See. See merupakan suatu kegiatan untuk melakukan refleksi terhadap pembelajaran yang telah berlangsung. Pada kegaiatan See, terlebih dahulu guru model diberi kesempatan untuk melaksanakan refleksi terhadap kegiatan pembelajaran yang telah dilakukannya, selanjutnya setiap pengamat (observer) diberi kesempatan untuk melaporkan hasil pengamatan. Setelah seluruh pengamat menyampaikan pengamatannya, kemudian, guru model bersama-sama dengan pengamat menyimpulkan kelebihan serta kekurangan dari kegiatan pembelajaran yang telah berlangsung. Selanjutnya, berdasarkann hal tersebut, guru model dan pengamat diminta menyampaikan masukan untuk pembelajaran berikutnya.

Lesson Study dalam pelaksanaannya memusatkan perhatian atau fokus ada siswa, sehingga melalui kegiatan ini, memberikan ruang bagi guru untuk memperbaiki proses pembelajarannya. Harapan dari proses ini, pembelajaran yang dilaksanakan akan memberikan kesempatan bagi siswa juga untuk mengambangkan pemahaman dan kemampuan kognitifnya. Kegiatan penyusunan dan pengembangan lesson plan yang dilaksanakan bersama oleh tim guru, diharapkan mampu memberi ruang pada siswa untuk membanhin pengetahuan melalui diskusi kelompok (peer colaboration) dan scafolding yang dilakukan guru terhadap siswa. Anggara dan Chotimah (2012) menyatakan bahwa implementasi kegiatan lesson study berbasis MGMP mampu memberikan dampak poditif terhadap peningkatan kompetensi profesional guru. Melalui kegiatan lesson study, guru sebagai peserta lesson study merasa diberi kesempatan untuk belajar bersama dan saling memberi masukan serta solusi antar sesama anggota lesson study. Berdasarkan beberapa hal tersebut, maka dirasa perlu untuk melatih mahasiswa calon guru untuk mengimplementasikan lesson study pada kegiatan microteaching dan dampaknya terhadap keterampilan mengajar.

\section{Metode Penelitian}

Penelitian dilaksanakan dengan pendekatan kualitatif. Jenis penelitian ini adalah penelitian deskriptif. Subyek dalam penelitian ini adalah seluruh mahasiswa semester VI kelompok C sebanyak 11 orang Mahasiswa Program Studi Pendidikan Matematika, Fakultas Keguruan dan Ilmu Pendidikan, Universitas Veteran Bangun Nusantara Sukoharjo. Penelitian dilakukan pada Mata Kuliah Microteaching yang dilaksanakan berbasis Lesson Study. Kesebelas mahasiswa tersebut adalah mahasiswa yang melaksanakan dalam jaringan menggunakan beberapa platform yaitu: Youtube, Sistem Pembelajaran dalam Jaringan Universitas Veteran Bangun Nusantara Sukoharjo 
dengan platform Moodle, Zoom, dan aplikasi Whatsapp. Metode pengumpulan data dilakukan dengan metode observasi. Instrumen yang digunakan dalam penelitian ini adalah: Lembar penilaian keterampilan mengajar dan lembar penilaian Rencana Pelaksanaan Pembelajaran. Kedua instrumen tersebut dilakukan untuk melakukan penilaian keterampilan mengajar dan Rencana Pelaksanaan Pembelajaran pada Open Lesson I, II, dan III. Tahapan penelitian terlihat pada Gambar 1. Instrumen penelitian yang berupa Lembar penilaian Lesson Plan terlihat pada Tabel 1. Sedangkan, instrumen yang berupa lembar penilaian keterampilan mengajar terlihat pada Tabel 2.

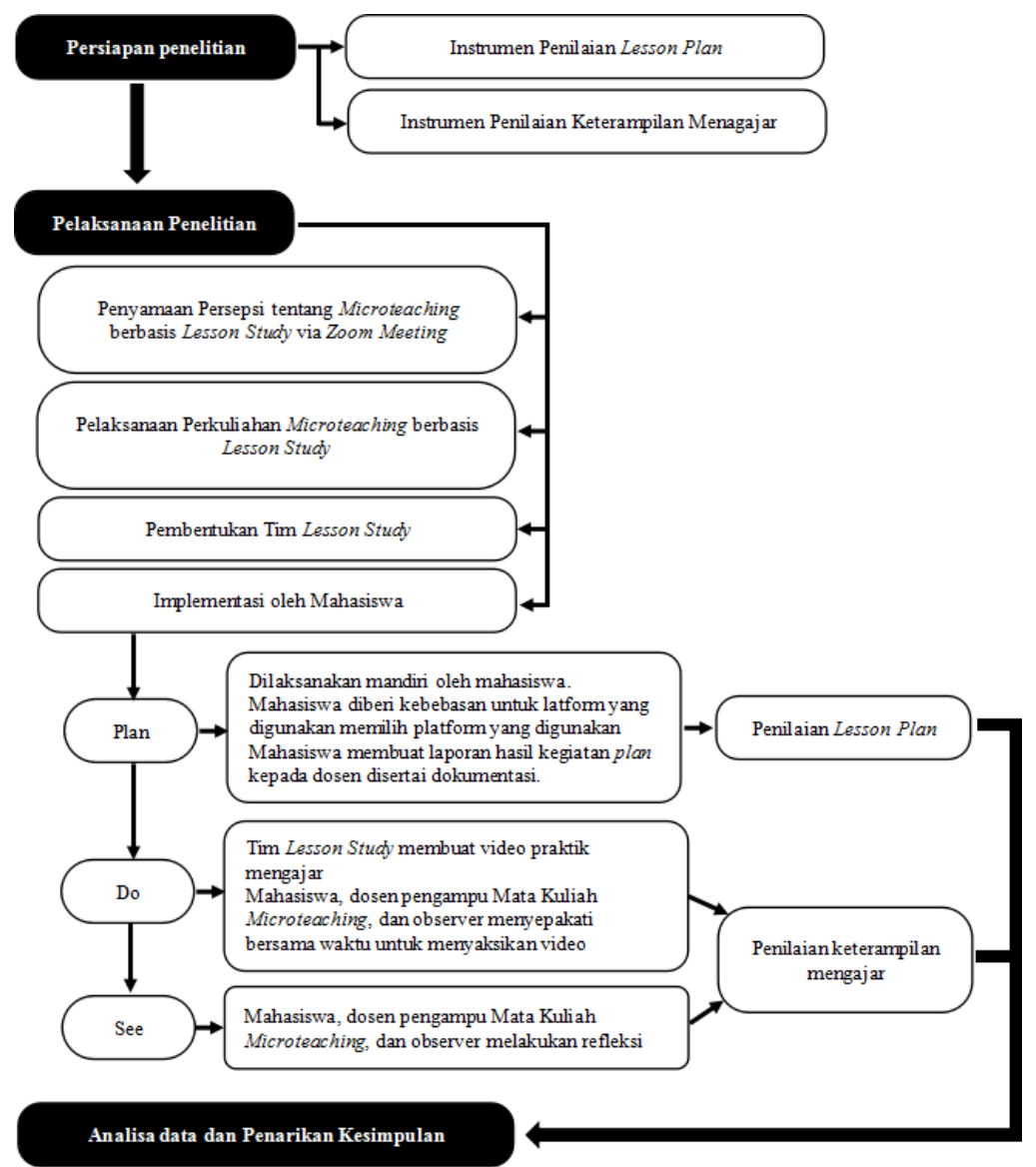

Gambar 1. Tahapan penelitian

Data yang telah terkumpul dari instrumen yang telah dikembangkan, akan dianalisis dengan menggunakan analisis data nonstatistik. Proses analisis data, baik data skor Lesson Plan maupun skor keterampilan mengajar menggunakan rumus sebagai berikut.

\section{Skor Lesson Plan}

Skor Lesson Plan Individu (LPI) $=\frac{\text { Skor }}{40} \times 100$ 
Rata-rata Skor Lesson Plan $(\mathrm{LP})=\frac{\sum \mathrm{LPI}}{\mathrm{n}}$ dengan $\mathrm{n}=$ banyak mahasiswa

Tabel 1 Lembar penilaian Lesson Plan

\begin{tabular}{clc}
\hline No & \multicolumn{1}{c}{ Komponen Penilaian } & \multicolumn{1}{c}{$\begin{array}{c}\text { Skor } \\
\text { Maks }\end{array}$} \\
\hline 1. & $\begin{array}{l}\text { Tujuan pembelajaran dirumuskan secara jelas, harus mengandung perilaku } \\
\text { hasil belajar, serta tidak menimbulkan penafsian ganda. }\end{array}$ & 5 \\
2. $\begin{array}{l}\text { Materi ajar yang dipilih sesuai dengan tujuan pembelajaran serta karaktersitik } \\
\text { peserta didik }\end{array}$ & 5 \\
3. & Materi ajar tidak terdapat miskonsepsi & 5 \\
4. $\begin{array}{l}\text { Materi disusun secara runtut, sesuai dengan materi dan alokasi waktu yang } \\
\text { ditentukan }\end{array}$ & 5 \\
5. $\begin{array}{l}\text { Sumber belajar dan media pembelajaran yang disusun sesuai dengan tujuan } \\
\text { pembelajaran, materi ajar, serta karakteristik peserta didik }\end{array}$ & 5 \\
6. $\begin{array}{l}\text { Skenario pembelajaran disusun dengan jelas dan runtut mulai dari kegiatan } \\
\text { awal, kegiatan inti serta penutup }\end{array}$ & 5 \\
7. $\begin{array}{l}\text { Teknik pembelajaran yang dipilih sesuai dengan tujuan yang telah ditetapkan } \\
\text { 8. } \begin{array}{l}\text { Instrumen penilaian lengkap, mulai dari soal, kunci jawaban, sampai pada } \\
\text { pedoman penskoran }\end{array}\end{array}$ & 5 \\
\hline
\end{tabular}

Sedangkan untuk Keterampilan Mengajar formula yang digunakan adalah sebagai berikut:

\section{Skor Keterampilan Mengajar}

Skor Keterampilan Mengajar Individu (KMI) = Skor total dari instrumen

Rata-rata Keterampilan Mengajar $(\mathrm{KM})=\frac{\sum \mathrm{KMI}}{\mathrm{n}}$ dengan $\mathrm{n}=$ banyak mahasiswa

\section{Hasil dan Pembahasan}

Tahapan pelaksanaan kegiatan implementasi Microteaching dalam jaringan berbasis Lesson Study dapat dijelaskan sebagai berikut.

\subsection{Tahap persiapan}

Kegiatan diawali dengan membentuk tim kecil mahasiswa. Tim yang dibentuk sebanyak 3 tim. Setiap tim tersebut akan melaksanakan kegiatan Lesson Study, serta setiap mahasiswa dalam tim mendapatkan kesempatan untuk menjadi guru model.

\subsection{Tahap pelaksanaan}

Tahap pertama yang dilaksanakan adalah plan (perencanaan). Kegiatan yang dilakukan pada tahap ini adalah penyusunan rancangan pembelajaran oleh mahasiswa 
yang berbasis pada permasalahan siswa. Kegaiatan plan dilaksanakan melalui pertemuan virtual menggunakan platform Zoom. Pada kegiatan plan, mahasiswa yang berkesempatan menajdi guru model menyampaikan kepada peserta plan mengenai rencana pembelajaran yang telah disusun, serta bagaimana rencana tersebut akan dijelaskan. Perangkat pembelajaran yang dipersiapka berupa RPP, bahan ajar, media pembelajaran, instrumen evaluasi serta sarana-prasarana lain yang akan digunakan. Anggota tim yang lain yaitu mahasiswa praktikan dalam tim tersebut beserta dosen Pembimbing diberi kesempatan untuk menyampaikan saran terhadap perencanaan yang telah disusun.

Tabel 2 Lembar penilaian keterampilan mengajar

\begin{tabular}{|c|c|c|}
\hline No & Komponen Penilaian & $\begin{array}{l}\text { Skor } \\
\text { Maks }\end{array}$ \\
\hline 1. & $\begin{array}{l}\text { Guru memiliki kecapakan dalam mempersiapkan peserta didik untuk } \\
\text { belajar }\end{array}$ & 5 \\
\hline 2. & Guru melaksanakan tahapan apersepsi & 5 \\
\hline 3. & Guru menguasai materi pembelajaran yang diajarkan & 5 \\
\hline 4. & $\begin{array}{l}\text { Guru mampu menyampaikan materi ajar secara jelas sesuai hierarki belajar } \\
\text { serta karakteristik peserta didik }\end{array}$ & 5 \\
\hline 5. & Guru melaksanakan kegiatan pembelajaran secara runtut & 5 \\
\hline 6. & Guru menunjukkan menguasan kelas yang baik & 5 \\
\hline 7. & $\begin{array}{l}\text { Guru melaksanakan kegaiatan pembelajaran yang mengarahkan peserta } \\
\text { didik pada tumbuhnya kebiasaaan positif }\end{array}$ & 5 \\
\hline 8. & $\begin{array}{l}\text { Guru melaksanakan kegaitan pembelajaran yang lebih mengaktifkan } \\
\text { peserta didik }\end{array}$ & 5 \\
\hline 9. & Media yang digunakan oleh guru digunakan secara efektif serta efisien & 5 \\
\hline 10. & Selama pembelajaran, guru menyampaikan pesan dengan menarik & 5 \\
\hline 11. & $\begin{array}{l}\text { Siswa terlibat dalam pemanfaatan media pembelajaran yang digunakan } \\
\text { oleh guru }\end{array}$ & 5 \\
\hline 12. & $\begin{array}{l}\text { Guru menunjukkan keterampilan untuk memunculkan partisipasi aktif } \\
\text { peserta dididk selama proses pembelajaran }\end{array}$ & 5 \\
\hline 13. & Guru bersikap terbuka terhadap respon yang diberikan peserta didik & 5 \\
\hline 14. & Guru mampu membuat peserta didik antusias selama proses pembelajaran & 5 \\
\hline 15. & $\begin{array}{l}\text { Selama proses pembelajaran, guru melakukan pemantauan kemajuan } \\
\text { belajar peserta didik. }\end{array}$ & 5 \\
\hline 16. & $\begin{array}{l}\text { Guru melaksanakan penilaian akhir yang sesuai dengan kompetensi yang } \\
\text { harus dicapai serta tujuan pembelajaran yang telah ditetapkan }\end{array}$ & 5 \\
\hline 17. & $\begin{array}{l}\text { Guru menunjukkan keterampilan penggunaan bahasa lisan dan tulis secara } \\
\text { jelas, baik dan benar }\end{array}$ & 5 \\
\hline 18. & $\begin{array}{l}\text { Guru mampu menyampaikan pesan kepada peserta didik dengan gaya yang } \\
\text { sesuai }\end{array}$ & 5 \\
\hline 19. & $\begin{array}{l}\text { Gurur melaksanakan kegiatan refleksi dan penarikan kesimpulan bersama- } \\
\text { sama dengan peserta didik. }\end{array}$ & 5 \\
\hline 20. & $\begin{array}{l}\text { Pada akhir pembelajaran, guru melaksanakan kegaiatan tindak lanjut } \\
\text { dengan melalui pemberian arahan, kegiatan, atau tugas baik sebagai bahan } \\
\text { remidi maupun bahan pengayaan. }\end{array}$ & 5 \\
\hline
\end{tabular}


Tahapan yang kedua adalah do (Pelaksanaan). Kegiatan do dalam penelitian ini dilaksanakan melalui 2 metode berikut. Pada metode pertama, dilaksanakan secara simultan oleh Guru Model, Observer serta peserta didik. Pelaksanaan pembelajaran dilakukan secara virtual melalui Platform Google Meet atau Zoom Meeting. Tahapan kegiatan do adalah sebagai berikut. (1) Guru model menjelaskan gambaran proses pembelajaran yang akan dilaksanakan kepada obsrver. Kegaiatan ini dilakukan sebelum siswa bergabung ke kelas virtual. (2) Pelaksanaan pembelajaran sesuai dengan rencana yang telah disusun. (3) Observer yang terdiri dari dosen pengampu Mata Kuliah Microteaching, dosen lain dan mahasiswa, mengamati serta mengumpulkan informasi mengenai aktivitas di kelas virtual. Kegiatan do dengan metode yang lain yaitu sebagai berikut. Guru model membuat sebuah video praktik pembelajaran. Selanjutnya, video tersebut disaksikan oleh guru model bersama dengan observer sesuai waktu yang telah disepakati bersama. Sebelum menyaksikan video pembelajaran observer mendapat penjelasan mengenai proses pembelajaran yang akan dilaksanakan hari dari guru model. Observer yang terdiri dari dosen dan mahasiswa mengamati aktivitas di kelas virtual serta mengumpulkan informasi yang ada.

Tahap ketiga adalah see (refleksi), yang dilaksanakan setelah kegiatan do. Halhal yang dilakukan pada tahapan ini adalah sebagai berikut. (1) Kegiatan diawali dengan penjelasan moderator mengenai aturan dalam refleksi. (2) Guru model menyampaiakn kesan selama pembelajaran. (2) Setiap observer berbagi informasi mengenai pembelajaran yang sudah berlangsung. (3) Tahapan berikutnya adalah bersama-sama mendiskusikan kekuatan dan kelemahan pelaksanaan pembelajaran yang sudah dilaksanakan. (6) Penarikan kesimpulan hasil observasi dan penyampaian usulan rekomendasi untuk perbaikan pembelajaran berikutnya.

\subsection{Evaluasi Kegiatan}

Berdasarkan hasil analisa data yang telah dilakukan, diperoleh data perubahan Skor Lesson Plan (LP) dan Skor Keterampilan Mengajar (KM) seperti terlihat pada Gambar 2. 


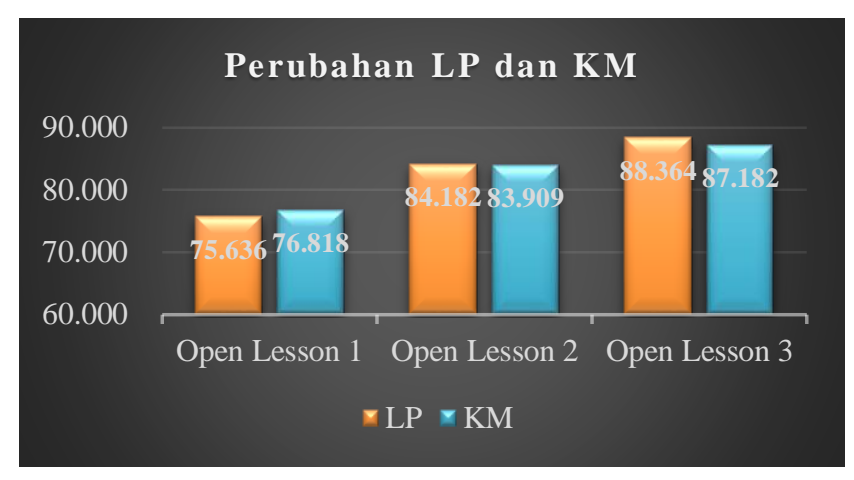

Gambar 2. Perubahan Skor LP dan KM

Berdasarkan gambar di atas dapat disimpulkan bahwa penerapan Microteaching dalam jaringan berbasis Lesson Study dapat meningkatkan kemampuan mahasiswa dalam menyusun Lesson Plan dan keterampilan mengajar mahasiswa. Hasil tersebut sejalan dengan hasil penelitian dari (Tedjawati, 2011) yang menyatakan bahwa salah satu dampak yang dirasakan oleh guru selama kegaiatan lesson study adalah meningkatnya kompetensi profesional guru. Guru menjadi lebih inovatif dengan mengaplikasikan berbagai metode pembelajaran yang variatif dan tentunya lebih relevan dengan kemampuan siswa. Melalui kegiatan lesson study ini juga, ternyata memberikan dampak pada peningkatan kualitas serta kuantitas Penelitian Tindakan Kelas (PTK) yang dilaksanakan oleh guru. Kegiatan Lesson Study ternyata mampu memberikan motivasi dan fasilitasi kepada seorang guru dalam melakukan inovasi pembelajaran, mulai dari kegiatan persipaan pembelaaran yang berupa Lesson Plan sampai pada kegiatan penyusunan rencana tindak lanjut untuk perbaikan pada pembelajaran berikutnya.

Hasil penelitian ini juga sejalan dengan pendapat dari (Anggara \& Chotimah, 2012) yang menyatakan bahwa dampak positif dari penerapan lesson study adalah meningkatnya kompetensi profesional guru. Hal ini disebabkan karena melalui kegiatan Lesson Study, guru diberi kesempatan untuk belajar bersama dan saling memberikan solusi serta masukan antar sesama anggota lesson study. Berdasarkan penelitian yang tekah dilakukan, Lesson study memberikan peluang kepada mahasiswa yang mengukuti setiap tahapan kegiatan lesson study untuk berdiskusi dan berlatih bersama untuk membuat Lesson Plan, menentukan media pembelajaran yang akan digunakan dengan memperhatikan karakteristik peserta didik, karakteristik materi, serta tujuan pembelajaran. Mahasiswa juga berlatih untuk menentukan metode pembelajaran yang sejalan dengan materi, yang arahnya untuk menciptakan suasana pembelajaran menjadi 
lebih efektif. Hal ini diperkuat dengan pembiasaan sikap terbuka terhadap masukan dari sesama praktikan maupun dosen dan oberver membuat praktikan lebih mudah mengembangkan proses pembelajaran.

Peningkatan keteranpilan menyusun Lesson Plan dan keterampilan mengajar mahasiswa meningkat setelah pelaksanaan kegiatan Microteaching dalam jaringan berbasis Lesson Study ini sejalan dengan hasil penelitian dari (Vitantri \& Asriningsih, 2016) yang menyatakan bahwa kompetensi mahasiswa sebagai calon guru matematika dalam menyususn RPP serta mengaplikasikan pembelajarannya menjadi meningkat setelah melaksanakan PPL I yang dijalankan berbasis Lesson Study. Hal ini dapat terjadi karena mahasiswa mampu merefleksi kelebihan dan kekurangan pembelajaran yang telah dilakukan. Melalui kegiatan ini mahasiswa sebagai calon guru diharapkan mampu mengungkap kekurangan dan kelemahan yang dimiliki selama pembelajaran untuk selanjutnya digunakan sebagai pijakan penyusunan rencana pembelajaran berikutnya. Setelah itu diharapkan mahasiswa memiliki kesadaran untuk melakukan perbaikanperbaikan untuk meminimalisir kekurangan atau kelemahan tersebut. Setelah refleksi dilakukan oleh mahasiswa praktikan selanjutnya dilaksanakan refleksi dari sesama mahasiswa praktikan yang berperan sebagai siswa sekaligus sebagai observer. Tujuan dilaksanakannya refleksi dari teman sejawat ini adalah untuk membiasakan diri memberi masukan bagi calon guru dari kacamata siswa dan kacamata observer. Refleksi dari sessama mahasiswa ini berkaitan dengan penguasaan kelas oleh calon guru serta interaksi antara guru dan siswa. Selanjutnya, setelah setiap sesama praktikan selesai memberikan masukan, dilanjutkan saran serta masukan dari dosen pembimbing untuk perbaikan pembelajaran selanjutnya. Setelah refleksi dari teman sejawat dilanjutkan refleksi dari dosen untuk mendapatkan saran-saran dan masukan dari dosen untuk perbaikan pembelajaran selanjutnya.

\section{Kesimpulan dan Saran}

Berdasarkan hasil analisa data disimpulkan bahwa penerapan Microteaching dalam jaringan berbasis Lesson Study dapat meningkatkan kemampuan mahasiswa dalam menyusun Lesson Plan dan keterampilan mengajar mahasiswa. Berdasarkan hasil penelitian, kegiatan Lesson Study mampu memberikan motivasi dan fasilitasi kepada calon guru yaitu mahasiswa praktikan untuk melakukan inovasi pembelajaran, mulai dari kegiatan persipaan pembelajaran sampai pada kegiatan penyusunan rencana tindak lanjut untuk perbaikan pada pembelajaran berikutnya. Sebagai tindak lanjut penelitian 
ini, dapat dikembangkan pelaksanaan kegiatan praktik mengajar di sekolah berbasis Lesson Study.

\section{Pustaka}

Agustiana, E., Putra, F. G., \& Farida, F. (2018). Penerapan Model Pembelajaran Auditory, Intellectually, Repetition (AIR) dengan Pendekatan Lesson Study terhadap Kemampuan Pemecahan Masalah Matematis Peserta Didik. Desimal: Jurnal Matematika, 1(1), 1. https://doi.org/10.24042/djm.v1i1.1905

Alamri, N. M. (2020). The Implementation of the Lesson Study Strategy in Teaching Mathematics: Teachers' Perspectives. Education Research International, 2020(1). https://doi.org/10.1155/2020/1683758

Andina, E. (2018). Efektivitas Pengukuran Kompetensi Guru. Aspirasi: Jurnal $\begin{array}{lll}\text { Masalah-Masalah Sosial, } & \text { 9(2), 204-220. }\end{array}$ https://doi.org/10.46807/aspirasi.v9i2.1103

Anggara, R., \& Chotimah, U. (2012). Penerapan Lesson Study Berbasis Musyawarah Guru Mata Pelajaran (MGMP) terhadap Peningkatan Kompetensi Profesional Guru PKn SMP Se-Kabupaten Ogan Ilir. Jurnal Forum Sosial, 5(2), 188-197. http://eprints.unsri.ac.id/1421/\%5Cnhttp://eprints.unsri.ac.id/1421/1/Penerapan_Le sson_Study_berbasis_MGMP_PKn.pdf

Anggraeni, P., \& Akbar, A. (2018). Kesesuaian Rencana Pelaksanaan Pembelajaran Dan Proses Pembelajaran. Jurnal Pesona Dasar, 6(2), 55-65. https://doi.org/10.24815/pear.v6i2.12197

Arman, A. (2016). Upaya Peningkatan Kompetensi Guru dalam Menyusun Rencana Pelaksanaan Pembelajaran Melalui Supervisi Akademik Kepala Sekolah di SMAN. Manajemen Pendidikan, I(1), 55-62.

Fahdini, R., Mulyadi, E., Suhandani, D., \& Julia. (2014). Identifikasi Kompetensi Guru Sebagai Cerminan Profesionalisme Tenaga Pendidik Di Kabupaten Sumedang. Mimbar Sekolah Dasar, 1(2), 33-42. https://doi.org/10.17509/mimbar-sd.v1i2.874

Karim, M. A. (2006). Implementation of Lesson Study for Improving the Quality of Mathematics Instruction in Malang. Tsukuba Journal Educational Study in Mathematic, 25, 67-73.

Kusumawati, R. (2020). The application of Lesson Study for LearningCommunity (LSLC)- based collaborative learning - Integrated Realistic Mathematics Education (RME) to improve the students' mathematical reasoning ability class IX D of MTSN 5 Jember on quadratic equation materia. Journal of Physics: Conference Series, 1563(1). https://doi.org/10.1088/1742-6596/1563/1/012060

Rohaeti, E. E., \& Hendriana, H. (2016). Penguasaan Guru Matematika Sekolah Menengah Terhadap Pembelajaran Inovatif Berbasis Penelitian Melalui Kegiatan Lesson Study. Edusentris, 3(3), 227. https://doi.org/10.17509/edusentris.v3i3.232

Sjunnesson, H. (2020). Initializing phase of lesson study: communication a special didactic tool in mathematics. International Journal for Lesson and Learning Studies, 9(3), 261-275. https://doi.org/10.1108/IJLLS-02-2020-0007 
Sya'Roni, A. R., Inawati, P. A., Guswanto, E., Susanto, \& Hobri. (2020). Students' creative thinking skill in the flipped classroom-blended learning of mathematics based on lesson study for learning community. Journal of Physics: Conference Series, 1563(1). https://doi.org/10.1088/1742-6596/1563/1/012046

Tachie, S. A. (2020). Teachers' Attitudes towards Lesson Study as a Viable Strategy to Improve the Teaching and Learning of Mathematics. Universal Journal of Educational Research, 8(6), 2326-2334. https://doi.org/10.13189/ujer.2020.080616

Tedjawati, J. (2011). Peningkatan Kompetensi Guru Melalui Lesson Study: Kasus Di Kabupaten Bantul. Jurnal Pendidikan Dan Kebudayaan, 17(4), 480-489. https://doi.org/10.24832/jpnk.v17i4.43

Vitantri, C. A., \& Asriningsih, T. M. (2016). Efektivitas Lesson Study Pada Peningkatan ( Effectiveness of Lesson Study. Jurnal Matematika Dan Pendidikan Matematika, I(1), 23-33. 
